Kalpa Publications in Civil Engineering
Volume 1, 2017, Pages 352-356
$\begin{gathered}\text { ICRISET2017. International Conference on Re- } \\ \text { search and Innovations in Science, Engineering } \\ \text { \&Technology. Selected papers in Civil Engineering }\end{gathered}$

\title{
Investigation on the Effect of Varying Dosages of Steel Fibre on the Strength and Workability Properties of High Strength Concrete
}

\author{
Dr. D.A.Sinha ${ }^{1,3}$ and Dr. A. K. Verma ${ }^{2,3}$ \\ ${ }^{1}$ Associate Professor, ${ }^{2}$ Professor \\ ${ }^{3}$ Structural Engineering Department, B.V.M. Engineering College, V.V.Nagar, Anand, India \\ dasinha@bvmengineering.ac.in, akverma@bvmeng ineering.ac.in
}

\begin{abstract}
In this work the strength characteristics of steel fibre reinforced concrete with varying percentages of fibres is found and hence arrived at optimum percentage of steel fibres. M60 grade concrete as per particle packing method was designed with cement, sand and coarse aggregates $(10 \mathrm{~mm}$ and $20 \mathrm{~mm})$ which yielded a proportion of 1:1.79:1.11:2.08 with a w/c ratio of 0.30 . The steel fibres were added at the rate of $0.5 \%, 0.75 \%, 1.0 \%, 1.25 \%, 1.50 \%, 1.75 \%$, and $2.0 \%$ by volume fraction. Based on the compressive strength and tensile strength it is concluded that the optimum percentage of steel fiber to be added in the concrete mix is $1 \%$ by volume fraction.
\end{abstract}

\section{Introduction}

Plain concrete has two major deficiencies; a low tensile strength and a low strain at fracture. The tensile strength of concrete is very low because plain concrete normally contains numerous microcracks. It is the rapid propagation of these microcracks under applied stress that is responsible for the low tensile strength of the material.

These deficiencies have led to considerable research aimed at developing new approaches to modifying the brittle properties of concrete. Current research has developed a new concept to increase the concrete ductility and its energy absorption capacity, as well as to improve overall durability. This new generation technology utilizes discrete steel or synthetic fibres from 19 to $64 \mathrm{~mm}$ in length. The fibres are randomly dispersed throughout the concrete matrix providing for better distribution of both internal and external stresses by using a three dimensional reinforcing network. ${ }^{1,2}$.. The role of 
randomly distributed discontinuous fibers is to bridge across the cracks that develop provides some post- cracking "ductility". Thus is resists the crack propagation. Even after the cracking the steel fibres hold the matrix of concrete and it will not allow more cracking.

\section{Objective}

Main objective of this study is to find out the workability and strength characteristics of steel fibre reinforced concrete with varying percentages of fibres and hence to arrive at optimum percentage of steel fibres.

\section{Material used}

- Cement: 53 Grade Ordinary Portland Cement (OPC), with specific gravity 3.15, initial setting time 120 minutes and final setting time 220 minutes, and 7 day compressive strength of $29 \mathrm{~N} / \mathrm{mm}^{2}$ and 28 day compressive strength of $54 \mathrm{~N} / \mathrm{mm}^{2}$, complying with IS: $12269-1987$ was used.

- Fine aggregates: Locally available sand with specific gravity of 2.62, falling under the zone-II, complying with IS:383 - 1970 was used.

- Coarse aggregates: $20 \mathrm{~mm}$ and $10 \mathrm{~mm}$ size aggregate: The crushed stone aggregates were collected from the local quarry Sevalia. The coarse aggregate (BLACK TRAP) used for the experiment were $20 \mathrm{~mm}$ and $10 \mathrm{~mm}$ down size and tested as per IS: 383-1970 and 2386-1963 (I, II and III) specifications. Specific gravity of coarse aggregates was found to be 2.82 and 2.78 respectively.

- Steel fibres: Steel fibers of $35 \mathrm{~mm}$ length and $0.7 \mathrm{~mm}$ thickness with crimped flat shape which gave an aspect ratio of 50 were used. The steel fiber was added by $1 \%$ of volume fraction. Crimped steel fibres were used, since it helps in proper bonding.

- Super plasticizer: Master Glenium sky 8860, complying with IS: 9103 - 1979 was used, to impart workability. It was based on Polycarboxlic ether. Super plasticizer content find out by marsh cone test. Super plasticizer was used at the rate of $1.5 \%$ by weight of cement.

\section{Procedure}

The mix design was carried out for M60 grade concrete as per Particle Packing Method (PPM), which yielded a proportion of 1:1.79:1.11:2.08 with a w/c ratio of 0.30 . The dosage of super plasticizer used was $1.5 \%$ (by weight of cement). The steel fibres were added at the rate of $0.5 \%, 0.75 \%, 1.0 \%$, $1.25 \%, 1.50 \%, 1.75 \%$, and $2.0 \%$ by volume fraction. The cement, sand and coarse aggregates were weighed according to the proportion of 1:1.79:1.11:2.08 and dry mixed. The required amount of water was added to this dry mix and intimately mixed. The calculated quantity of super plasticizer was now added and mixed thoroughly. After this, different percentage of steel fibers ( $0.5 \%$ up to $2 \%)$ by volume was added to the mix and the entire concrete was agitated thoroughly to get a homogeneous mix. Then the mix was placed layer by layer in the moulds to cast the specimens. The specimens were prepared both by hand compaction as well by imparting vibrations through vibrating table. The specimens were finished smooth and kept under wet gunny bags for 24 hours after which they were cured for 7 days and 28 days by immersing them in water. 
Investigation on the Effect of Varying Dosages of Steel Fibre... Dr. D. A. Sinha and Dr. A. K. Verma

Test results: Different test results such as compressive strength and tensile strength and flexural strength.

Overall results of compressive strength: Following table 1, gives the overall results of compressive strength of concrete with different percentage of steel fibres. The compressive strength test as per IS: 516-1969 is carried out on $150 \times 150 \times 150 \mathrm{~mm}$ standard cubes after 7 days of curing and 28 days of curing period. The cubes were tested using compression testing machine having 200 tons capacity. Also it gives the percentage increase or decrease of compressive strength w.r.t. reference mix.

\begin{tabular}{ccccc}
$\begin{array}{c}\text { Percentage of } \\
\text { steel fibres added }\end{array}$ & $\begin{array}{l}7 \text { days strength } \\
\text { Average }\end{array}$ & $\begin{array}{c}\text { Percentage } \\
\text { compressive strength } \\
\text { increase or decrease of } \\
\text { compresssive strength } \\
\text { w.r.t. ref. mix }\end{array}$ & $\begin{array}{l}\text { Average } \\
\text { compressive strength } \\
(\mathrm{MPa})\end{array}$ & $\begin{array}{l}\text { Percentage } \\
\text { increase or decrease of } \\
\text { compresssive } \\
\text { s.rength }\end{array}$ \\
\hline $0 \%$ & 60.741 & - & 70.3704 & - \\
\hline $0.50 \%$ & 61.481 & 1.216 & 71.8519 & 2.105289 \\
\hline $0.75 \%$ & 62.815 & 3.414 & 72.8889 & 3.578 \\
\hline $1.00 \%$ & 64.593 & 6.3416 & 73.037 & 3.7891 \\
\hline $1.25 \%$ & 62.222 & 2.4382 & 72.5926 & 3.1578 \\
\hline $1.50 \%$ & 62.074 & 2.1945 & 72.2963 & 2.7368 \\
\hline $1.75 \%$ & 61.778 & 1.7072 & 71.7037 & 1.8946 \\
\hline $2.00 \%$ & 61.185 & 0.73097 & 71.2593 & 1.2631 \\
\hline
\end{tabular}

TABLE 1 OVERALL RESULT OF COMPRESSIVE STRENGTH

Overall results of tensile strength: Following table 2 gives the overall results of tensile strength of concrete with different percentage of steel fibres. The tensile strength test as per IS: 516-1969 is carried out on $150 \times 300 \mathrm{~mm}$ standard cylinders after 7 days of curing and 28 days of curing period. The cylinders were tested using compression-testing machine having 200 tons capacity. In addition, it gives the percentage increase or decrease of tensile strength w.r.t. reference mix.

\begin{tabular}{|c|c|c|c|c|}
\hline \multirow{2}{*}{$\begin{array}{c}\text { Percentage of } \\
\text { steel fibres added }\end{array}$} & \multicolumn{2}{|c|}{7 days strength } & \multicolumn{2}{|c|}{28 days strength } \\
\hline & \begin{tabular}{ll}
\multicolumn{2}{c}{ Average } \\
tensile & strength \\
(MPa) & \\
\end{tabular} & $\begin{array}{l}\text { Percentage increase } \\
\text { or decrease of tensile } \\
\text { strength w.r.t. ref. mix }\end{array}$ & \begin{tabular}{ll}
\multicolumn{2}{c}{ Average } \\
tensile & strength \\
(MPa) & \\
\end{tabular} & $\begin{array}{l}\text { Percentage increase } \\
\text { or decrease of tensile } \\
\text { strength w.r.t. ref. mix }\end{array}$ \\
\hline $0 \%$ & 3.6518 & - & 3.92545 & - \\
\hline $0.50 \%$ & 3.7839 & 3.61757 & 4.05756 & 3.36538 \\
\hline $0.75 \%$ & 4.2368 & 16.0195 & 4.69922 & 19.7116 \\
\hline $1.00 \%$ & 4.3501 & 19.12208 & 4.81246 & 22.5963 \\
\hline $1.25 \%$ & 4.3218 & 18.34711 & 4.78415 & 21.8751 \\
\hline $1.50 \%$ & 4.3123 & 18.08697 & 4.72281 & 20.3125 \\
\hline $1.75 \%$ & 4.2746 & 17.0546 & 4.68507 & 19.3511 \\
\hline $2.00 \%$ & 4.2038 & -1.6556 & 4.6143 & 17.5483 \\
\hline
\end{tabular}

\section{TABLE 2 OVERALL RESULT OF TENSILE STRENGTH}

Overall results of flexural strength: The flexural strength test as per IS: 516-1969 is carried out on $100 \times 100 \times 500 \mathrm{~mm}$ standard beams after 7 days and 28 days of curing. The beams were tested under two point loading using UTM having 50 tons capacity. The results are shown in table 3 which gives the overall results of flexural strength of concrete with different percentage of steel fibres. Also it gives the percentage increase or decrease of flexural strength w.r.t. reference mix. 


\begin{tabular}{|c|c|c|c|c|}
\hline \multirow{2}{*}{$\begin{array}{l}\text { Percentage } \\
\text { of steel fibres } \\
\text { added }\end{array}$} & \multicolumn{2}{|c|}{7 days strength } & \multicolumn{2}{|c|}{28 days strength } \\
\hline & $\begin{array}{l}\text { Average } \\
\text { flexural } \\
\text { strength } \\
\text { (MPa) }\end{array}$ & $\begin{array}{l}\text { Percentage increase or } \\
\text { decrease of flexural strength } \\
\text { w.r.t. ref. mix }\end{array}$ & $\begin{array}{l}\text { Average } \\
\text { flexural } \\
\text { strength } \\
\text { (Mpa) }\end{array}$ & $\begin{array}{l}\text { Percentage increase or } \\
\text { decrease of flexural strength } \\
\text { w.r.t. ref. mix }\end{array}$ \\
\hline $0 \%$ & 6.96 & - & 7.3066 & - \\
\hline $0.50 \%$ & 7.25333 & 4.215 & 7.7866 & 6.569 \\
\hline $0.75 \%$ & 7.4 & 6.322 & 7.8666 & 7.664 \\
\hline $1.00 \%$ & 8.18667 & 17.625 & 8.5733 & 17.336 \\
\hline $1.25 \%$ & 8.253333 & 18.582 & 8.5866 & 17.518 \\
\hline $1.50 \%$ & 8.306666 & 19.349 & 8.6 & 17.701 \\
\hline $1.75 \%$ & 8.333333 & 19.732 & 8.6133 & 17.883 \\
\hline $2.00 \%$ & 8.4 & 20.69 & 8.6266 & 18.066 \\
\hline
\end{tabular}

TABLE 3 OVERALL RESULTS OF FLEXURAL STRENGTH

Observations and discussions: Table 1 shows variation of compressive strength after 7 days and 28 days of curing. It is found that with the increase in fibre content up to $1 \%$, the strength is increasing i.e. compressive strength is found to be higher at $1 \%$ fibre content and with further increase in fibre content the strength is decreasing. It is found that $1 \%$ addition of steel fibres result in $6.34 \%$ and $3.79 \%$ increase in 7 days and 28 days compressive strength respectively. Higher percentage addition of fibres substantially decreases the compressive strength as can be seen from table 1.This may be due to the fact that the addition of higher percentage of steel fibres may lead to congestion of fibres causing balling effect and improper bonding with concrete. Thus it can be concluded that addition of $1 \%$ steel fibres results in higher compressive strength and use of more than $1 \%$ steel fibres will bring down the compressive strength.

Similar trends are observed for tensile strength. It is found that $1 \%$ addition of steel fibres result in $19.12 \%$ and $22.60 \%$ increase in 7 days and 28 days tensile strength respectively. Higher percentage addition of fibres substantially decreases the tensile strength as can be seen from table 2.This may be due to the fact that the presence of steel fibres delays the development of fine cracks and their prorogation. Also the presence of fibres reduces the widening of cracks, thus resulting in improvement in the load carrying capacity of the composite. However there is a limit up to which the fibre content can be increased due to the balling effect and improper bonding with concrete. Thus it can be concluded that addition of $1 \%$ steel fibres results in higher tensile strength and use of more than $1 \%$ steel fibres will bring down the tensile strength.

It is found that the flexural strength goes on increasing as the percentage of steel fibres in it increases as seen from table 3 . When $2 \%$ steel fibres are added the flexural strength is found to increase by $20.69 \%$ and $18.06 \%$ for 7 days curing and 28 days curing periods. This is due to the fact that as the amount of fibre in the composite increases it greatly helps in curbing the formation, propogation and widening of cracks more effectively thus resulting in increase of flexural strength. The ductile behavior of the beam was observed due to the effective bridging action of fibers across the cracks. Thus it can be concluded that addition of $2 \%$ steel fibres results in higher flexural strength. 
Investigation on the Effect of Varying Dosages of Steel Fibre... Dr. D. A. Sinha and Dr. A. K. Verma

\section{Conclusions}

Following conclusions may be drawn based on the observations.

- Addition of $1 \%$ steel fibres result in higher compressive strength and use of more than $1 \%$ steel fibres will bring down the compressive strength.

- Addition of $1 \%$ steel fibres result in higher tensile strength and use of more than $1 \%$ steel fibres will bring down the tensile strength.

- Flexural strength is found to increase as the percentage of steel fibres in it increases.

- Based on the compressive strength and tensile strength results it can be concluded that the optimum percentage of steel fibre to be added in the concrete mix is $1 \%$ by volume fraction.

\section{References}

Deepa A Sinha,A k Verma, Pradeep Chauhan," Concrete mix design by particle packing method, International Conference on Futuristic Trends in Engineering, Science, Pharmacy and Management, 23-24December- 2016

ACI Committee, "State of the art report in fibre reinforced concrete" ACI 554 IR - 82 Detroit Mechigan 1982 (pp. 153-201)

Nataraja M. C., Dhang N. and Gupta A. P, “Splitting tensile strength of SFRC.”Indian Concrete Journal, April 2001, (pp 287-290) 